\title{
Online Political Flashmob: the Case of 632305222316434
}

\author{
A.P. Petrov*, S.A. Lebedev \\ Keldysh Institute of Applied Mathematics RAS, Moscow, Russian Federation
}

This paper considers the case of online flashmob 63230522231643, which was intended to show the indignation of Russian opposition to the contested parliamentary elections in 2011. The expression of indignation lasted for 47 days. The organizers called on all who believed that the elections had been rigged to enter the aforementioned number anywhere on the internet so that it could be indexed by search engines. The assumption was that the number could hardly be expected to appear in any context other than the flashmob. Thus, using the Google search engine and counting its appearances, anyone would be able to estimate the extent or severity of indignation, which was the political opposition members thought was as very widespread. However, the flashmob mobilized only a small number of participants and failed to achieve its political goals. At the same time, it turned out to be a rare example of the spread of information in a world that was sparse, that is, considering only those individuals whose political attitudes and dispositions to online activity made them available for participation, we get a social network with relatively few edges, which is a sub-network of a denser and larger network of users.

Methods. The paper presents empirical data on the daily number of flashmob-related tweets and presents a mathematical model to describe the dynamics of a flashmob on Twitter and compare the results of modeling with empirical data for flashmob 63230522231643.

Results. The model correctly represents and explains some important features of the dynamics of a flashmob. To explain the other features would require more a more complex model and building and verifying such a model would call for more abundant empirical data.

Keywords: online flashmob, sparse world, twitter, political protest, mathematical modeling, rumor models.

Introduction. In the aftermath of the parliamentary elections that were held on December 4, 2011, the code number or the string of digits, 632305222316434 was published on the Russian segment of Twitter for those who wished to participate in the Flashmob (written as beginning with capital F to indicate the specific Flashmob that is the subject of this paper, when used in other contexts such as discussing mathematical theory propagation, the word is not capitalized.). The results of the elections, when announced, were strongly contested. Masses of people were seething and one of the attempted actions of protest was the call [1] by an otherwise unremarkable Livejournal user «spichechka» (which means «little match» referring to a matchstick and its potential to cause a fire)

\footnotetext{
*E-mail: petrov.alexander.p@yandex.ru
} 
for those who believed that the elections had been rigged to publish the number 632305222316434 in their blogs, websites or anywhere on the internet so that it could be indexed by search engines. The idea was that this number could hardly appear in any other context. When typed into the Google search engine, the engine would instantly show the number of times it appears. This would indicate to the searcher the extent of indignation, which the opposition thought to be extremely wide. However, the Flashmob did not get support from any major opposition web resource, newspaper or prominent politicians. As it failed to mobilize the expected huge number of participants, the attempt failed to achieve its political goals.

One more probable reason for the failure is that some participants posted the code number of the Flashmob without making any accompanying comment such as «I post this number to express my indignation...». It is possible that some sympathizers came across this 15 -digital number but did not realize what it implied. They may have thought that «Maybe, the string of random digits appeared simply because the sender's cat walked over the keyboard...». We mention this possibility to point out that when recipients come across a post with the code number, they do not necessarily recognize the significance of the post and recognize it as a signal of a protestors' Flashmob. Though this may not be the major reason for Flashmob's failure, this possible reason needs to be pointed out because in the mathematical model below there is a parameter describing the probability of coming across a certain post and recognizing it as a part of a flashmob and thus learning about the flashmob from it.

However, the failure of the Flashmob is not very apparent. Google search engine finds 20000 to 32000 results for the query «632305222316434» (it is not clear why this count is so variable). That would lead to the conclusion [2] that there were 20-30 thousand participants, so when planning this study an abundance of statistics was expected to be available. However, a kind of political fraud (or trick) aimed at exaggerating the number of participants was discovered instead.

That fraud utilized the online database of smart questions that have been used in a popular TV show and an intellectual game called «What? Where? When?». Any user may upload a question into the database, and the question creates a new webpage.

The fraud was that the webpage designer inserted the number 632305222316434 into the footer of the page template of this database. As a result, 20000 (for instance) questions resulted in the creation of 20000 pages containing the number in the footer. The Google search, as expected, counted these 20000 pages as if 20000 people had supported the protest against the results of the Parliamentary election. (And even today in 2019 the number of fake protesters has continued to rise as users continue to upload new questions to the website). The number 632305222316434 can easily be seen at the bottom of the screenshot of the webpage given in Appendix 1. The scale of the fraud is not clear because the database claims it has more than 337 thousand game tasks. That number is ten times more the count that the Google search shows, though each page of that database contains the said code number. Probably, not all the pages are indexed by Google. Anyway, the webpages of this database [3] account for the overwhelming majority of mentions of the number 632305222316434.

The motivation behind this fraud seems obvious. The whole idea of the Flashmob was to show a very huge number of people did not accept the results of the parliamentary election. Therefore, the opponents were keen to exaggerate the number of participants. 
After eliminating the numbers that were added as a result of the fraud, we were left with a small number of genuine citations of 632305222316434 , the vast majority of them being from Livejournal and Twitter.

As for the number of the Flashmob-related posts in Livejournal, the Google search for the number 632305222316434 on livejournal.com yields 1920 pages (accessed 18 June 2019). This presumably means several hundred participants of the Flashmob, because each post in Livejournal appears in several layouts (single post, feed, month, tag1-related feed, tag2-related feed, etc.) and thus generates substantially more than one results in Google search. For example, the search query "632305222316434 on podmoskovnik.livejournal.com gives 16 results (Appendix 2) though they all relate to a single participant of the Flashmob.

Future flashmobs are more likely to appear in Twitter than in Livejournal as the latter seems to have been losing its popularity. For this reason, this study turned to the spread of the Flashmob on Twitter, where 211 participants of the Flashmob were found over 47 days.

This duration far longer than a day (or even a few hours) that a political message requires to reach nearly everyone who may be interested in it. The probable reason for the difference is that the Flashmob is a very rare instance of the spread of information in a sparse world. That is, considering only individuals whose political attitudes and dispositions to online activity made them available for participation in the Flashmob. This resulted in a social network with a relatively small number of edges, embedded in a denser and greater network of users. Also taking into account that people were not so much involved in using social media in 2011 as they are today and watched their feeds less often than they do nowadays, it's not surprising that the Flashmob had only a few participants and that, too, over an unusually long duration.

Introductory Notes and Some Connections to the Literature. It follows from the last paragraph of Section 1 that the network density is pivotal for the speed of propagation of the Flashmob. However, this does not necessarily mean that the mathematical model of the Flashmob must have a design that explicitly accounts for the participants' network, its structure, and density. (It should be noted that the empirical part of this research was conducted several years after the Flashmob. Therefore, it was not possible to separate the connections between users that existed before the time of the Flashmob from those that were established later).

The model below deals with macro-variables such as the number of flashmob-related posts or number of persons aware of the flashmob. This approach is in line with classical models of rumor propagation by Daley \& Kendall [4] and Maki \& Thompson [5] as well as the recent models [6-13] (see [14] for a very brief review).

Note that spichechka's call to publish «632305222316434» (which we refer to as seeding post) was never published on TV or newspaper. Thus, the information about the Flashmob was transmitted exclusively by the participants of it, making an example of rumor transmission.

Other approaches to mathematical modeling of rumors and propaganda wars include emphasis on position selection, opinion dynamics, social networks, and agent-based and game theory-based models [14-21]. Related empirical studies usually focus on the content of the posts or search queries (see, for example, [22-24]). Broader contexts include Internet security, cyberwars and cybersecurity [25-27]. 
Mathematical Model. Let us start with numbering days: $t=0,1,2,3, \ldots$ where $t=0$ is the day the seeding post was published. Let $N_{0}$ be the number of potential participants, that is the number of individuals whose political attitudes and network positions make them available for participation. Each of them is not supposed to post the number 63230522231643 more than once. We categorize all of the individuals into three groups:

$-n(t)$ is the current number of participants, that is, persons who have already published their posts by the start of the day $\mathrm{t}$ (obviously, $n(t)$ is also the number of posts);

$-c(t)$ is the number of cunctators, that is, persons who are aware of the Flashmob but have not posted yet by the start of the day $t$;

$-g(t)$ is the number of ignorants, that is, persons who are not aware of the Flashmob by the start of the day $t$.

At any moment of time we have $n(t)+c(t)+g(t)=N_{0}$.

An ignorant can turn into a cunctator or a participant. Also, a cunctator can turn into the participant. Denote $\Delta_{g \rightarrow c}(t)$ the number of ignorants turned into cunctators on day $t$, that is the number of persons who belong among the ignorants at the start of the day $\mathrm{t}$ and will belong to cunctators at the start of the day $t+1$. Similarly, $\Delta_{g \rightarrow n}(t), \Delta_{c \rightarrow n}(t)$ are the numbers of ignorants and cunctators turned into participants. Thus, we have

$$
\begin{aligned}
& g(t+1)=g(t)-\Delta_{g \rightarrow c}-\Delta_{g \rightarrow n} \\
& c(t+1)=c(t)+\Delta_{g \rightarrow c}-\Delta_{c \rightarrow n} \\
& n(t+1)=n(t)+\Delta_{g \rightarrow n}+\Delta_{c \rightarrow n}
\end{aligned}
$$

Let $q$ denote the probability that the average individual uses their account on day $\mathrm{t}$ so that they learn about the Flashmob (if they are ignorant) or/and make their post on that day. This probability is supposed to be unaffected by the individual's group. Hence, the total number of persons using their account on day $\mathrm{t}$ is $N_{0} q(t)$, and among these persons are:

- $q n(t)$ participants,

- $q c(t)$ cunctators, and

- $q g(t)$ ignorants.

Consider an individual using their account on day $t$ and seeing a certain post that has been published at the start of that day. Let $\mathrm{p}$ denote the probability that they come across this post and recognize it as a part of the flashmob, thus learning about the flashmob. Then the probability that this individual learns about the Flashmob from at least one of the $n(t)$ posts of the Flashmob is

$$
P=1-(1-p)^{n(t)} \text {. }
$$

Therefore, the number of ignorants who learned about the Flashmob on day $\mathrm{t}$, that is the number of persons who turned from being ignorants into being either cunctators or participants is

$$
\Delta_{g \rightarrow c}(t)+\Delta_{g \rightarrow n}(t)=q g(t) P(t)=q g(t)\left[1-(1-p)^{n(t)}\right] .
$$


Let $\mathrm{w}$ denote the probability that a person who uses their account on day $\mathrm{t}$, and is aware of the Flashmob (no matter whether they learned about it on this very day or any day earlier), will make their post on day $\mathrm{t}$.

Using this, we can split the number $\Delta_{g \rightarrow c}(t)+\Delta_{g \rightarrow n}(t)$ of persons leaving the ignorant group as $\Delta_{g \rightarrow c}=(1-w)\left(\Delta_{g \rightarrow c}(t)+\Delta_{g \rightarrow n}(t)\right), \Delta_{g \rightarrow n}=w\left(\Delta_{g \rightarrow c}(t)+\Delta_{g \rightarrow n}(t)\right)$, that is

$$
\begin{aligned}
& \Delta_{g \rightarrow c}=(1-w) q g(t)\left[1-(1-p)^{n(t)}\right], \\
& \Delta_{g \rightarrow n}=w q g(t)\left[1-(1-p)^{n(t)}\right] .
\end{aligned}
$$

The number of cunctators turning into participants is

$$
\Delta_{c \rightarrow n}=w q c(t)
$$

Putting (5)-(7) into (1)-(3), we obtain

$$
\begin{aligned}
& g(t+1)=g(t)-q g(t)\left[1-(1-p)^{n(t)}\right], \\
& c(t+1)=c(t)+(1-w) q g(t)\left[1-(1-p)^{n(t)}\right]-w q c(t), \\
& n(t+1)=n(t)+w q g(t)\left[1-(1-p)^{n(t)}\right]+w q c(t),
\end{aligned}
$$

Equations (8)-(10) present the model of an online flashmob. Obviously, given $n(t)+s(t)+g(t)=N_{0}$, one of the equations (8)-(10) can be omitted.

(A situation can be easily imagined where flashmob-related political views become increasingly popular, and the pool of persons attitudinally available for participation increases over time. This case of a continuous increase would give rise to a term $g(t)(1+r)$ instead of $g(t)$ in equation (8); in this case $N_{0}$ is not constant).

Consider now the realistic case of $p<<1$. That is, the probability that an average ignorant will learn about the flashmob from a certain post is low. This is the case of the sparse net of sympathizers embedded into a dense net of other users. Suppose, for example, that an ignorant follows 500 Twitter accounts, only one of them has published their post inviting support for the flashmob. In this case, the probability must be relatively low that the ignorant will come across this post and pay enough attention to it so as to learn about the flashmob.

As $p<<1$, we can take the following approximation:

$$
1-(1-p)^{n(t)} \approx 1-[1-p n(t)]=p n(t)
$$

Putting this into (8)-(10), we obtain the model in the case of a sparse net of sympathizers:

$$
\begin{aligned}
& g(t+1)=g(t)-p q n(t) g(t), \\
& c(t+1)=c(t)+(1-w) p q n(t) g(t)-w q c(t), \\
& n(t+1)=n(t)+w p q n(t) g(t)+w q c(t) .
\end{aligned}
$$


Model (12)-(14) must be considered for $t \geq 1$ and supplemented with initial conditions for the number of posts published during day $t=0$ (which is an observable value) and the number of cunctators at the start of the day $t=1$ (not observable), that is $n(1)$ and $s(1)$.

As $n(1)$ posts of the day $t=0$ comprises the seeding post and $n(1)-1$ succeeding posts, we assume that the number of cunctators is $s(1)=(n(1)-1)(1-w) / w$. This completes the construction of the model.

Discussion and Application of the Model to the Case of 632305222316434. The daily number of tweets with code number 63230522231643 is presented in Appendix 3. By applying ordinary least squares to this model the following estimates are obtained: $N_{0}=239, q=0.16$, $p=0.02, w=0.69$.

Both empirical and model curves are shown in Fig. 1. As the daily number of posts is relatively small, we rounded the numbers on each iteration when calculating the «theoretical» (predicted by the model (12)-(14)) results.

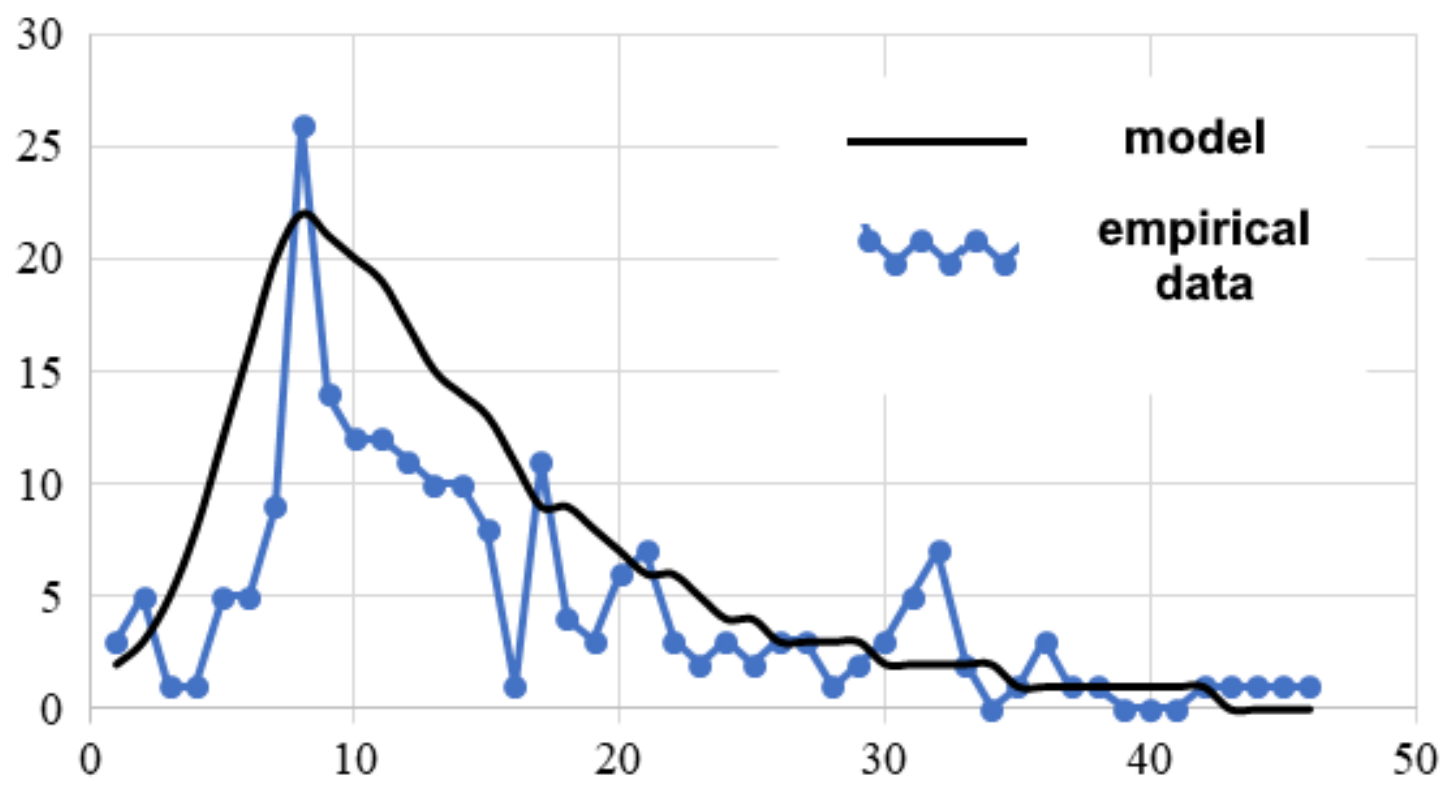

Fig. 1. Empirical data and model curve. Horizontal and vertical axes represent days $t$ and daily number of posts $n(t)-n(t-1)$, respectively.

The obvious problem with matching is the fluctuation of the empirical data. As we said earlier, the statistics were expected to be much more abundant. The paucity of data naturally implies high fluctuation.

The second problem is that the model failed to describe the sharp empirical peak at $t=8$. We conducted massive numerical experiments with the model (including those with and without direct relation to empirical data) and found that the result yielded by the model clearly tended to show relatively broad and low peak. The cause for this is probably that the model assumes individuals to be psychologically identical. It is pertinent here to refer to the study of public attention to one-time 
political events such as referendums, elections or coups [28]. That study dealt with empirics and mathematical modeling of the dynamics of the number of search queries about the event. The empirical curve (the number of search queries as a function of time) was very sharp, having the double-exponential shape such as $\exp [3.94+2.91 \exp (-0.19 t)]$ (Russia's public attention to Brexit) or $\exp [3.16+3.73 \exp (-0.23 t)]$ (Russia's public attention to the US Presidential Elections of 2016). Mathematical models that assume psychological sameness of the individuals (which are close in their philosophy to models employing the concept of «representative individual» of «representative household») are unable to describe this double-exponential empirical regularity. Accordingly, paper [28] builds on the assumption that individuals are differentially predisposed towards being interested in a given event (for example, because the individuals are not equally interested in politics) and constructs the model to explain the sharp double-exponential decrease of public attention as a result of this differential predisposition. Thus, it looks highly probable that in explaining the sharpness of the peak in Fig. 1, the notion of differential predisposition towards online political activity would be crucial. Though, the examination of this hypothesis requires richer empirical data.

What is clear even with sparse statistics is that model (12)-(14) successfully explains the asymmetry of the curve: the increase of the daily number of posts before the peak is obviously steeper than the decrease of it after the peak. The reason is that some people procrastinate before posting, that is, they are cunctators. Removing the class of cunctators (that is, assuming $w=1$ ) from the model would lead to a much more symmetrical solution. The smaller is $w$, the longer and more gradual is the decrease of the daily number of posts, the greater is asymmetry.

To summarize, the model correctly represents and explains some important features of the process. Explaining other features requires more abundant empirical data to build and verify a more complex model.

\section{References}

1. https://spichechka.livejournal.com/221514.html (last accessed 2019-06-07).

2. http://www.wikireality.ru/wiki/632305222316434 (last accessed 2019-06-07).

3. Online database of smart questions https://db.chgk.info, https://kand.info, https://bazavoprosov.ru/, https://ww.w.chgk7.ru, https://www.pdf.baza-voprosov.ru, https://zaba.ru/ (the list of URLs may be incomplete; last accessed 2019-06-07).

4. D. J. Daley, D. G. Kendall. Stochastic rumors // Journal of the Institute of Mathematics and its Applications, vol. 1, pp. 42-55, 1964.

5. D. P. Maki, M. Thompson. Mathematical Models and Applications, Prentice-Hall, Englewood Cliffs, NJ, USA, 1973.

6. Chen, G., Shen, H., Ye, T., Chen, G., Kerr, N. A kinetic model for the spread of rumor in emergencies // Discrete Dyn. Nat. Soc. 2013, 1-8 (2013).

7. Isea, R., Mayo-Garcia, R. Mathematical analysis of the spreading of a rumor among different subgroups of spreaders // Pure Appl. Math. Lett. 2015, 50-54 (2015).

8. Huo, L., Huang, P., Guo, C. Analyzing the dynamics of a rumor transmission model with incubation // Discrete Dyn. Nat. Soc. 2012, 1-21. Article ID 328151. (2012). 
9. Kawachi, K. Deterministic models for rumor transmission // Nonlinear Anal. Real World Appl. 9(5), 1989-2028 (2008).

10. Dickinson, R.E., Pearce, C.E.M. Rumours, epidemics, and processes of mass action: synthesis and analysis // Math. Comput. Model. 38(11-13), 1157-1167 (2003).

11. Mikhailov, A.P. and Marevtseva, N.A. Models of information warfare // Mathematical models and computer simulations, 4(3), pp.251-259 (2012).

12. Kereselidze, N. Combined continuous nonlinear mathematical and computer models of the Information Warfare // International Journal of Circuits, Systems and Signal Processing.Vol.12, p.220-228 (2018).

13. Kereselidze, N., Mathematical and Computer Models of Non-Permanent Information Warfare // WSEAS Transactions on Systems 18 (Art. \#8), 73-80 (2019).

14. Petrov A., Proncheva O. Modeling Propaganda Battle: Decision-Making, Homophily, and Echo Chambers. In: Ustalov D., Filchenkov A., Pivovarova L., Žižka J. (eds) Artificial Intelligence and Natural Language. AINL 2018. Communications in Computer and Information Science, vol 930. Springer. P. 197-209. DOI: 10.1007/978-3-030-01204-5_19 (2018).

15. Mikhailov A. P., Petrov A. P., Proncheva O. G. Modeling the effect of political polarization on the outcome of propaganda battle // Computational mathematics and information technologies. 2017. - No 1. - P. 65-81. doi:10.23947/2587-8999-2017-1-1-65-81.

16. Kozitsin, I. V., Belolipetskii, A. A. Opinion convergence in the Krasnoshchekov model // The Journal of Mathematical Sociology, 43(2), 104-121 (2019).

17. Kozitsin, I. V. Generalization of Krasnoshchekov's model for the case of a decomposable matrix of social interactions // Mathematical Models and Computer Simulations, 10(4), 398-406 (2018).

18. Chkhartishvili A.G., Gubanov D.A., Novikov D.A. Social Networks: Models of information influence, control and confrontation. - Springer, 2019, 158 p.

19. Chkhartishvili, A., Kozitsin, I. Binary Separation Index for Echo Chamber Effect Measuring. In 2018 Eleventh International Conference» Management of large-scale system development» MLSD (pp. 1-4). IEEE (2018).

20. Doerr, B., Fouz, M., Friedrich, T.: Why rumors spread so quickly in social networks // Commun. ACM 55(6), 70-75 (2012).

21. Zhang, Y., Tang, C., Weigang, L.: Cooperative and competitive dynamics model for information propagation in online social networks // J. Appl. Math. 2014, 1-12 . Article ID 610382 (2014).

22. Akhtyamova L., Ignatov A., Cardiff J. A Large-Scale CNN Ensemble for Medication Safety Analysis. In: Frasincar F., Ittoo A., Nguyen L., Métais E. (eds) Natural Language Processing and Information Systems. NLDB 2017. Lecture Notes in Computer Science, vol 10260. Springer, Cham. pp. 247-253/. https://link.springer.com/chapter/10.1007/978-3-319-59569-6_29 (2017).

23. Boldyreva A., Sobolevskiy O., Alexandrov M., Danilova V. Creating collections of descriptors of events and processes based on Internet queries // Proc. of 14-th Mexican Intern. Conf. on Artif. Intell. (MICAI-2016). - Springer Cham, LNAI, vol. 10061 (chapter 26), p. 303-314, //https://link.springer.com/chapter/10.1007/978-3-319-62434-1_26 (2016). 
24. Boldyreva A., Alexandrov M., Koshulko O., Sobolevskiy O. Queries to Internet as a tool for analysis of the regional police work and forecast of the crimes in regions // Proc. of 14-th Mexican Intern. Conf. on Artif. Intell. (MICAI-2016). - Springer Cham, LNAI, v. 10061 (chapter 25), p. 290302, // https://link.springer.com/chapter/10.1007/978-3-319-62434-1_25 (2016).

25. Rocca, N.M. Internet security facing Jihadist propaganda in Europe: the last challenge for society? // Cahiers des IFRE, No 4. (2017).

26. Korobiichuk, I., Hryshchuk, R., Mamarev, V., Okhrimchuk, V. and Kachniarz, M. Cyberattack Classificator Verification // International Conference on Diagnostics of Processes and Systems (pp. 402-411). Springer, Cham (2017)

27. Mishra, B.K. and Prajapati, A. Modelling and simulation: cyber war. Procedia Technology, 10, pp.987-997 (2013).

28. A.P. Mikhailov, A. P. Petrov, G. B. Pronchev and O. G. Proncheva. Modeling a Decrease in Public Attention to a Past One-Time Political Event // Doklady Mathematics, Vol. 97, No. 3, pp. 247-249. ISSN 1064-5624. doi: 10.1134/S1064562418030158 (2018).

\section{APPENDIX 1.}

The screenshot of https://db.chgk.info/question/belch16.2/1 which represents the evidence of the fraud aimed at exaggerating the number of participants. The Flashmob number can be seen at the footer. Other websites of the online database of smart questions employ the same template with 632305222316434 in the footer.

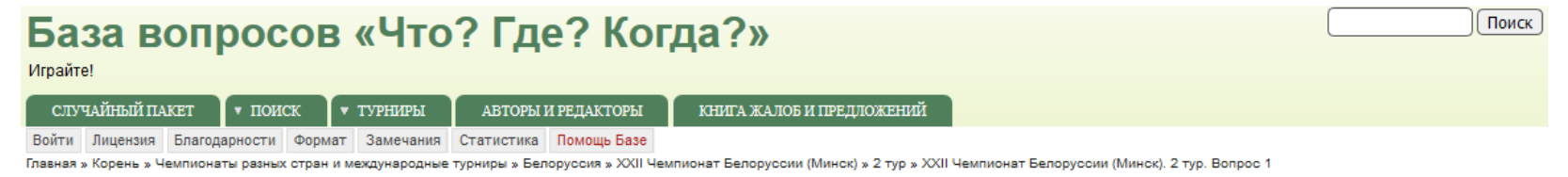

XXII Чемпионат Белоруссии (Минск). 2 тур. Вопрос 1

Вопрос 1: На Олимпийских играх 1920 года Тереза Вельд стала первой женщиной, выполнившей новый элемент, и завоевала бронзовую медаль. Однако многих не устроило, что ОНА оказалась на такой высоте. Назовите ЕE. Ответ: Юбка.

Комментарий: Фигуристка Тереза Вельд первой среди женщин выполнила сальхов. Во время прыжка юбка высоко задиралась, и это было сочтено неприпичным. До появпения 3имних Олимпииад в 1924 году фигурное катание вкпючапось в программу Летних Опимпийсих игр: Источник(и): http://ru.wikipedia.org/wiki/Cальхов_(прыжок) Автор: Мишель Матвеев (Санкт-Петербург) 


\section{APPENDIX 2}

This list of URLs illustrates that a single user can generate as many as 16 results on the Google search (query: 632305222316434 site: podmoskovnik.livejournal.com)

1. https://podmoskovnik.livejournal.com/133050.html

2. https://podmoskovnik.livejournal.com/tag/

3. https://podmoskovnik.livejournal.com/133289.html

4. $\quad$ https://podmoskovnik.livejournal.com/tag/\%D1\%82\%D0\%BE\%D1\%88 $\% \mathrm{D} 0 \% \mathrm{BD} \% \mathrm{D} 0 \% \mathrm{BE} \% \mathrm{D} 1 \% 82 \% \mathrm{D} 0 \% \mathrm{~B} 2 \% \mathrm{D} 0 \% \mathrm{BE} \% \mathrm{D} 1 \% 80 \% \mathrm{D} 0 \% \mathrm{BD} \% \mathrm{D} 1 \% 8 \mathrm{~B} \% \mathrm{D} 0 \% \mathrm{~B} 5 \% 20 \%$ D0\%B4\%D0\%B5\%D0\%B1\%D0\%B8\%D0\%BB\%D1\%8B

5. $\quad$ https://podmoskovnik.livejournal.com/tag/\%D0\%A7\%D1\%83\%D1\%80\%D0 $\% \mathrm{BE} \% \mathrm{D} 0 \% \mathrm{~B} 2 \% 20 \% \mathrm{D} 1 \% 81 \% \mathrm{D} 0 \% \mathrm{BC} \% \mathrm{D} 0 \% \mathrm{BE} \% \mathrm{D} 1 \% 82 \% \mathrm{D} 1 \% 80 \% \mathrm{D} 0 \% \mathrm{~B} 8 \% \mathrm{D} 1 \% 82 \% 20 \% \mathrm{D} 0$ $\% \mathrm{BD} \% \mathrm{D} 0 \% \mathrm{~B} 0 \% 20 \% \mathrm{D} 0 \% \mathrm{~B} 2 \% \mathrm{D} 0 \% \mathrm{~B} 0 \% \mathrm{D} 1 \% 81$

6. $\quad$ https://podmoskovnik.livejournal.com/tag/\%D1\%81\%D1\%82\%D1\%80 $\% \mathrm{D} 0 \% \mathrm{~B} 0 \% \mathrm{D} 0 \% \mathrm{BD} \% \mathrm{D} 0 \% \mathrm{BD} \% \mathrm{D} 0 \% \mathrm{BE} \% \mathrm{D} 0 \% \mathrm{~B} 5$

7. $\quad$ https://podmoskovnik.livejournal.com/tag/\%D0\%B2\%D0\%B5\%D0\%BD $\% \mathrm{D} 1 \% 82 \% \mathrm{D} 0 \% \mathrm{~B} 8 \% \mathrm{D} 0 \% \mathrm{BB} \% \mathrm{D} 1 \% 8 \mathrm{~F} \% \mathrm{D} 1 \% 82 \% \mathrm{D} 0 \% \mathrm{BE} \% \mathrm{D} 1 \% 80$

8. https://podmoskovnik.livejournal.com/tag/ \%D0\%B1\%D1\%80\%D0\%B5\%D0\%B4

9. https://podmoskovnik.livejournal.com/tag/ \%D0\%BF\%D0\%B5\%D0\%B0\%D1\%80

10. $\quad$ https://podmoskovnik.livejournal.com/tag/\%D0\%B2\%D1\%81\%D0\%B5 $\% 20 \% \mathrm{D} 1 \% 83 \% \mathrm{D} 0 \% \mathrm{~B} 6 \% \mathrm{D} 0 \% \mathrm{~B} 5 \% 20 \% \mathrm{D} 1 \% 83 \% \mathrm{D} 0 \% \mathrm{BA} \% \mathrm{D} 1 \% 80 \% \mathrm{D} 0 \% \mathrm{~B} 0 \% \mathrm{D} 0 \% \mathrm{~B} 4 \% \mathrm{D} 0 \% \mathrm{~B} 5$ \%D0\%BD\%D0\%BE\%20\%D0\%B4\%D0\%BE\%20\%D0\%BD\%D0\%B0\%D1\%81

11. https://podmoskovnik.livejournal.com/tag/ \%D1\%81\%D1\%83\%D0\%BA\%D0\%B8

12. https://podmoskovnik.livejournal.com/tag/politics

13. https://podmoskovnik.livejournal.com/tag/ \%D1\%8F\%D0\%B2\%D0\%BA\%D0\%B0

14. https://podmoskovnik.livejournal.com/tag/\%D0\%A2\%D1\%80\%D0\%BE $\% \mathrm{D} 0 \% \mathrm{~B} 8 \% \mathrm{D} 1 \% 86 \% \mathrm{D} 0 \% \mathrm{BA} \% \mathrm{D} 0 \% \mathrm{~B} 8 \% \mathrm{D} 0 \% \mathrm{~B} 9 \% 20 \% \mathrm{D} 0 \% 92 \% \mathrm{D} 0 \% \mathrm{~B} 0 \% \mathrm{D} 1 \% 80 \% \mathrm{D} 0 \% \mathrm{~B} 8 \% \mathrm{D} 0$ $\% \mathrm{~B} 0 \% \mathrm{D} 0 \% \mathrm{BD} \% \mathrm{D} 1 \% 82$

15. $\quad$ https://podmoskovnik.livejournal.com/tag/\%D0\%BF\%D0\%B0\%D0\%BC $\% \mathrm{D} 1 \% 8 \mathrm{~F} \% \mathrm{D} 1 \% 82 \% \mathrm{D} 1 \% 8 \mathrm{C}$

16. $\quad$ https://podmoskovnik.livejournal.com/tag/\%D0\%B3\%D0\%BE\%D1\%81 $\% \mathrm{D} 1 \% 83 \% \mathrm{D} 0 \% \mathrm{~B} 4 \% \mathrm{D} 0 \% \mathrm{~B} 0 \% \mathrm{D} 1 \% 80 \% \mathrm{D} 1 \% 81 \% \mathrm{D} 1 \% 82 \% \mathrm{D} 0 \% \mathrm{~B} 2 \% \mathrm{D} 0 \% \mathrm{~B} 5 \% \mathrm{D} 0 \% \mathrm{BD} \% \mathrm{D} 0 \% \mathrm{~B}$ D\%D0\%B0\%D1\%8F\%20\%D0\%B4\%D1\%83\%D0\%BC\%D0\%B0 


\section{APPENDIX 3}

Empirical data: the daily number of tweets with 63230522231643 . The seeding post was made on December 6, 2011; thus $t=1$ refers to December 7.

\begin{tabular}{|c|c|c|c|c|c|c|c|c|c|c|}
\hline Day (t) & 1 & 2 & 3 & 4 & 5 & 6 & 7 & 8 & 9 & 10 \\
\hline Number of tweets & 3 & 5 & 1 & 1 & 5 & 5 & 9 & 26 & 14 & 12 \\
\hline
\end{tabular}

\begin{tabular}{|c|c|c|c|c|c|c|c|c|c|c|}
\hline Day $(\mathrm{t})$ & 11 & 12 & 13 & 14 & 15 & 16 & 17 & 18 & 19 & 20 \\
\hline Number of tweets & 12 & 11 & 10 & 10 & 8 & 1 & 11 & 4 & 3 & 6 \\
\hline
\end{tabular}

\begin{tabular}{|c|c|c|c|c|c|c|c|c|c|c|}
\hline Day $(\mathrm{t})$ & 21 & 22 & 23 & 24 & 25 & 26 & 27 & 28 & 29 & 30 \\
\hline Number of tweets & 7 & 3 & 2 & 3 & 2 & 3 & 3 & 1 & 2 & 3 \\
\hline
\end{tabular}

\begin{tabular}{|c|c|c|c|c|c|c|c|c|c|c|}
\hline Day $(\mathrm{t})$ & 31 & 32 & 33 & 34 & 35 & 36 & 37 & 38 & 39 & 40 \\
\hline Number of tweets & 5 & 7 & 2 & 0 & 1 & 3 & 1 & 1 & 0 & 0 \\
\hline
\end{tabular}

\begin{tabular}{|c|c|c|c|c|c|c|c|c|c|c|}
\hline Day $(\mathrm{t})$ & 41 & 42 & 43 & 44 & 45 & 46 & 47 & 48 & 49 & 50 \\
\hline Number of tweets & 0 & 1 & 1 & 1 & 1 & 1 & 0 & 0 & 0 & 0 \\
\hline
\end{tabular}

\section{Authors:}

Petrov Alexander P., Dr.Sci. (Math), Leading Researcher at Keldysh Institute of Applied Mathematics (4, Miusskaya Sq., Moscow, Russian Federation)

Lebedev Sergei A., Postgraduate Student at Keldysh Institute of Applied Mathematics (4, Miusskaya Sq., Moscow, Russian Federation) 


\section{Политический онлайн-флэшмоб 632305222316434}

\section{А.П. Петров*, А.С. Лебедев}

Институт прикладной математики им. М.В. Келдыша РАН

Предмет исследования. $\mathrm{B}$ статье рассматривается случай онлайн-флешмоба 63230522231643, который должен был продемонстрировать негодование российской оппозиции по поводу оспариваемых парламентских выборов 2011 года. Организаторы призвали всех полагавших, что выборы были сфальсифицированы, разместить указанное число в любом месте в Интернете, чтобы оно могло быть проиндексировано поисковыми системами. Идея заключалась в том, что это число вряд ли могло появиться в каком-либо другом контексте. Таким образом, используя количество страниц с данным числом, найденных поисковой системой Google, каждый желающий смог бы оценить размах негодования, который представлялся членами политической оппозиции как очень широкая. Однако флэшмоб не получил поддержки ни от одного крупного оппозиционного веб-ресурса, газеты или известного политика. В результате он мобилизовал лишь небольшое количество участников и не смог достичь своих политических целей. В то же время, флэшмоб представляет собой редкий примером распространения информации в так называемом разреженном мире. Другими словами, пользователи, чьи политические установки и готовность к онлайн-активности делают их доступными для участия, составляют социальную сеть с относительно небольшим количеством ребер, которая является подсетью более плотной и крупной сети. Методы. В статье представлены эмпирические данные о ежедневном количестве твитов, участвующих во флешмобе. Также построена математическая модель для описания динамики флешмоба в Твиттере и проведено сравнение результатов моделирования с эмпирическими данными. Результаты. Модель правильно представляет и объясняет некоторые важные особенности динамики флэшмоба. Для объяснения других особенностей требуется больший объем эмпирических данных, позволяющий построить и квантифицировать более сложную модель.

Ключевые слова: онлайн флешмоб, разреженный мир, Твиттер, политический протест, математическое моделирование, модели слухов.

\section{Авторы:}

Петров Александр Пхоун Чжо, доктор физико-математических наук, ведущий научный сотрудник Института прикладной математики им. М.В. Келдыша РАН (РФ, г. Москва, Миусская пл., 4)

Лебедев Сергей Александрович, аспирант Института прикладной математики им. М.В. Келдыша РАН (РФ, г. Москва, Миусская пл., 4)

\footnotetext{
* E-mail: petrov.alexander.p@yandex.ru
} 